\title{
Pengaruh Keinginan Pasangan Usia Subur (Pus) dalam Penggunaan Metode Kontrasepsi Jangka Panjang
}

\author{
Sumartini dan Diah Indriani \\ Departemen Biostatistika dan Kependudukan \\ Fakultas Kesehatan Masyarakat Universitas Airlangga \\ Jl. Mulyorejo Kampus C Unair Surabaya 60115 \\ Alamat Korespondensi: \\ Sumartini \\ Email:mtini14@gmail.com
}

\begin{abstract}
One of the most effective effort in the family planning program was to control fertilitas and press the population growth rate was used contraception. In the area of Puskesmas Pacar Keling Surabaya interest of acceptor which used short term contraceptive method still high than long term contraceptive method. This research used analytical observational study with case control methods. The population is all woman reproductive age couples aged 15-49 years old in the area of Puskesmas Pacar Keling Surabaya. Sampling technique used two stage random sampling and got 90 respondent. The variables were age, knowledge, side effects, desire to have a child again, husband and family support. Data were analyzed with multiple logistic regression with al level of significance value $\alpha=0,05$. The result of logistic regression analysis significant variables were age $(p=0,002)$, side effects $(p=0,005)$, desire to have a child again $(p=0,028)$, husband and family support $(p=0,008)$. Conclusion of research is that age, side effects, desire to have more children, husband and family support influencing reproductive age couples using long term contraceptive methods. This research suggest health workers provide Counselling and information about Family Planning to reproductive age couples specially they were 20-30 years old about explanation of the use of long term contraception method.
\end{abstract}

Keywords: reproductive age couples, long term contraceptive

\begin{abstract}
ABSTRAK
Salah satu upaya dalam Program Keluarga Berencana untuk pengendalian fertilitas atau menekan laju pertumbuhan penduduk yang paling efektif adalah penggunaan kontrasepsi. Di wilayah kerja Puskesmas Pacar Keling Surabaya minat akseptor yang memakai Non-Metode Kontrasepsi Jangka Panjang (Non-MKJP) masih tinggi dibandingkan Metode Kontrasepsi Jangka Panjang (MKJP). Metode penelitian studi analitik observasional dengan menggunakan case control study. Populasi penelitian yaitu semua wanita PUS yang berusia 15-49 tahun berstatus menikah di wilayah kerja Puskesmas Pacar Keling Surabaya. Cara pengambilan sampel menggunakan teknik two stage random sampling dan didapatkan sampel sebanyak 90 responden. Variabel yang diteliti yaitu umur, pengetahuan, efek samping, ingin punya anak lagi, dukungan suami dan keluarga. Data dianalisis menggunakan teknik regresi logistik ganda menggunakan tingkat signifikansi $\alpha=0,05$. Hasil uji regresi logistik didapatkan variabel yang signifikan yaitu umur $(\mathrm{p}=0,002)$, efek samping $(\mathrm{p}=0,005)$, ingin punya anak lagi $(\mathrm{p}=0,028)$, dukungan suami dan keluarga $(p=0,008)$. Variabel umur, efek samping, keinginan mempunyai anak lagi, dukungan suami dan keluarga memengaruhi keinginan PUS dalam penggunaan MKJP. Penelitian ini menyarankan kepada petugas kesehatan KB memberikan konseling dan informasi pada Pasangan Usia Subur (PUS) yang berumur 20-30 tahun tentang penjelasan penggunaan MKJP yang aman.
\end{abstract}

Kata kunci: pasangan usia subur, metode kontrasepsi jangka panjang

\section{PENDAHULUAN}

Program Keluarga Berencana (KB) mempunyai kontribusi penting dalam pembangunan sumber daya manusia yang berdampak pada peningkatan kualitas penduduk. Salah satu dilihat dari Dilihat dari pelaksanaan program Making Pregnancy Safer (MPS) yaitu setiap pasangan usia subur yang ingin hamil harus merencanakan kehamilannya. Pemilihan alat kontrasepsi yang tepat disesuaikan dengan kebutuhan dan indikasi akseptor yang ingin menggunakan (Manuaba, 2009). 
Rencana Pembangunan Jangka Menengah Nasional (RPJMN tahun 2010-2014) mengarahkan pengendalian kelahiran penduduk dengan tiga prioritas, yaitu: revitalisasi program $\mathrm{KB}$, menyerasikan kebijakan pengendalian penduduk, meningkatkan ketersediaan dan kualitas data yang akurat dan tepat waktu. Di dalam dokumen RPJMN menyebutkan bahwa dalam rangka mempercepat pengendalian jumlah angka kelahiran penduduk melalui program penggunaan metode kontrasepsi. Secara nasional program KB yang ada di Indonesia lebih diarahkan pada penggunaan Metode Kontrasepsi Jangka Panjang (MKJP) dibandingkan NonMetode Kontrasepsi Jangka Panjang (NonMKJP) (Witjaksono, 2012).

Metode KB di Indonesia terbagi menjadi dua macam yaitu MKJP dan Non-MKJP. MKJP meliputi Alat Kontrasepsi Dalam Rahim (AKDR), Implant/susuk, Metode Operasi Wanita (MOW) dan Metode Operasi Pria (MOP) dan Non-MKJP meliputi suntik, pil dan kondom. Di Jawa Timur sampai dengan bulan Desember tahun 2014 peserta KB baru Non-MKJP sebesar 84,75 persen dari jumlah seluruh peserta KB baru, sedangkan yang menggunakan MKJP sebesar 15, 25 persen (BKKBN, 2014). Masih rendahnya penggunaan MKJP dipengaruhi oleh faktor akseptor dan penyedia pelayanan kesehatan $\mathrm{KB}$ yaitu tenaga kesehatan. Faktor yang berkontribusi dengan kecenderungan akseptor memilih Non-MKJP adalah akseptor menerima informasi dari gambar yang ada di pelayanan kesehatan. Mencerna gambar dari informasi yang ada di pelayanan kesehatan (BKKBN, 2011).

Sementara itu, Survei Sosial Ekonomi Nasional tahun 2012 (Susenas, 2012) memperlihatkan data penggunaan alat kontrasepsi Provinsi Jawa Timur menunjukkan masih didominasi Non-MKJP dibandingkan penggunaan MKJP. Jumlah peserta KB aktif sebesar 65,68 juta jiwa. Jika di rinci penggunaan Non-MKJP terbanyak adalah suntik 59,21 persen, pil 22,95 persen, kondom pria 0,48 persen, dan intravag/kondom wanita 0,04 persen. Pengguna MKJP yaitu IUD/AKDR 7,27 persen, implant 5,14 persen, MOW 3,13 persen, dan MOP 0,46 persen (Susenas, 2012).

Faktor yang memengaruhi partisipasi PUS mengikuti program $\mathrm{KB}$ adalah masih rendahnya pengetahuan tentang $\mathrm{KB}$, sosial budaya masyarakat, dan cara untuk mengakses pelayanan KB. Beberapa faktor lain yang menjadi pemicu kekhawatiran akseptor untuk menggunakan alat kontrasepsi yaitu terjadi efek samping setelah pemakaian alat kontrasepsi dan adanya risiko penyakit yang timbul, risiko penyakit tersebut adalah penyakit hipertensi, jantung dan diabetes melitus. Akibatnya banyak akseptor takut sebelum dikonsultasikan ke petugas kesehatan yang lebih mengerti masalah alat kontrasepsi $\mathrm{KB}$ (Kurnia, 2008).

Berdasarkan hasil survei di Puskesmas Pacar Keling Surabaya jumlah peserta KB aktif pada bulan Januari-Desember 2014 sebesar 7.428 akseptor. Peserta KB aktif yang menjadi peserta KB suntik sebesar 3.260 orang 43,89 persen, pil 1.408 orang 18,96 persen, kondom 218 orang 2,93 persen, IUD 1.300 orang 17,50 persen, Implant 592 orang 7,97 persen, MOW 746 orang 10,04 persen, dan MOP 4 orang 0,05 persen. Berdasarkan data tersebut, terlihat masih tingginya angka pemakaian Non-MKJP dibandingkan MKJP pada akseptor KB. Tujuan dari penelitian ini untuk mengetahui pengaruh keinginan PUS terhadap penggunaan metode kontrasepsi jangka panjang.

\section{METODE PENELITIAN}

Penelitian ini merupakan penelitian analitik observasional, dengan desain penelitian menggunakan cross sectional study. Populasi dalam penelitian yaitu semua wanita Pasangan Usia Subur (PUS) yang berusia 15--49 tahun dalam keadaan menggunakan alat kontrasepsi KB dan berstatus menikah di wilayah kerja Puskesmas Pacar Keling Surabaya. Teknik sampling pertama menggunakan two stage random sampling, untuk menentukan RW yang digunakan dalam satu kelurahan. Hasil dari penghitungan terpilih $2 \mathrm{RW}$ dari $12 \mathrm{RW}$. Teknik sampling kedua menggunakan simple random sampling untuk mengetahui jumlah sampel yang digunakan di tiap RW yang terpilih. Terpilih di masing-masing RW yaitu 42 responden dan 48 responden. Jumlah total sampel dalam penelitian ini sebanyak 90 responden. Pengumpulan data dengan menggunakan lembar kuesioner. Kriteria inklusi sampel adalah bersedia menjadi responden 
dalam penelitian, wanita PUS usia antara 15-49 tahun, menggunakan Metode Kontrasepsi Jangka Panjang dan Non-Metode Kontrasepsi Jangka Panjang. Penelitian ini dilakukan di wilayah kerja Puskesmas Pacar Keling Surabaya pada bulan Desember 2015.

Variabel penelitian terdiri dari variabel independen yaitu umur, pengetahuan, efek samping, dukungan suami dan keluarga. Variabel dependen yaitu penggunaan Metode Kontrasepsi Jangka Panjang. Teknik analisis data menggunakan regresi logistik ganda.

\section{HASIL PENELITIAN}

\section{Hubungan Umur dengan Keinginan PUS Menggunakan MKJP}

Pengaruh umur responden dengan keinginan PUS menggunakan MKJP dapat dilihat pada Tabel 1.

Tabel 1 menunjukkan mayoritas responden umur 20-30 tahun menggunakan Non-MKJP, sedangkan mayoritas umur $>30$ tahun menggunakan MKJP. Hubungan umur responden dengan keinginan PUS menggunakan metode kontrasepsi jangka panjang menunjukkan nilai $\mathrm{p}=0,000(\mathrm{p}<\alpha, \alpha=0,05)$ ada hubungan bermakna antara umur dengan penggunaan MKJP.

\section{Hubungan Tingkat Pengetahuan dengan Keinginan PUS Menggunakan MKJP}

Hubungan tingkat pengetahuan responden dengan keinginan PUS menggunakan MKJP dapat dilihat pada Tabel 1 .

Tabel 1 menunjukkan sebagian besar responden memiliki pengetahuan MKJP baik, Non-MKJP kurang. Hubungan tingkat pengetahuan responden dengan keinginan PUS menggunakan MKJP, menunjukkan nilai $\mathrm{p}=0,702(\mathrm{p}>\alpha, \alpha=0,05)$. Berarti bahwa tidak ada hubungan bermakna antara tingkat pengetahuan dengan pengguna MKJP.

\section{Hubungan Efek Samping dengan Keinginan PUS Menggunakan MKJP}

Efek samping yang pernah dialami responden saat menggunakan MKJP dapat dilihat pada Tabel 1.

Tabel 1 menunjukkan mayoritas responden yang pernah mengalami efek samping adalah menggunakan Non-MKJP. Responden yang sedikit mengalami efek samping menggunakan MKJP. Hubungan efek samping responden dengan keinginan PUS menggunakan MKJP menunjukkan nilai $p=0,004(p<\alpha, \alpha=0,05)$. Berarti bahwa ada hubungan bermakna antara efek samping dengan pengguna MKJP.

Tabel 1. Distribusi Metode KB dengan Keinginan PUS dalam Penggunaan MKJP

\begin{tabular}{|c|c|c|c|c|c|c|c|c|}
\hline \multirow{2}{*}{ Variabel } & \multirow{2}{*}{ Kategori } & \multicolumn{2}{|c|}{ MKJP } & \multicolumn{2}{|c|}{ Non-MKJP } & \multicolumn{2}{|c|}{ Total } & \multirow{2}{*}{$\mathbf{p}$} \\
\hline & & n & $\%$ & $\mathbf{n}$ & $\%$ & $\mathbf{n}$ & $\%$ & \\
\hline \multirow{3}{*}{ Umur } & $<20$ tahun & 0 & 0 & 3 & 100 & 3 & 100 & \multirow{3}{*}{0,000} \\
\hline & 20-30 tahun & 15 & 30,0 & 35 & 70,0 & 50 & 100 & \\
\hline & $>30$ tahun & 30 & 81,1 & 7 & 18,9 & 37 & 100 & \\
\hline \multirow{3}{*}{ Pengetahuan } & Baik & 6 & 60,0 & 4 & 40,0 & 10 & 100 & \multirow{3}{*}{0,702} \\
\hline & Cukup & 13 & 54,2 & 11 & 45,8 & 24 & 100 & \\
\hline & Kurang & 26 & 46,4 & 30 & 53,6 & 56 & 100 & \\
\hline \multirow{2}{*}{ Efek samping } & Pernah & 22 & 38,0 & 36 & 62,0 & 58 & 100 & \multirow{2}{*}{0,004} \\
\hline & Tidak pernah & 23 & 71,9 & 9 & 28,1 & 32 & 100 & \\
\hline \multirow{2}{*}{ Ingin punya anak lagi } & Ingin & 14 & 30,4 & 32 & 69,9 & 46 & 100 & \multirow{2}{*}{0,000} \\
\hline & Tidak ingin & 31 & 70,5 & 13 & 29,5 & 44 & 100 & \\
\hline \multirow{2}{*}{ Dukungan suami dan keluarga } & Ya & 13 & 28,9 & 32 & 71,1 & 45 & 100 & \multirow{2}{*}{0,000} \\
\hline & Tidak & 32 & 71,1 & 13 & 28,9 & 45 & 100 & \\
\hline
\end{tabular}




\section{Hubungan Keinginan Mempunyai Anak Lagi dengan Penggunaan MKJP}

Keinginan mempunyai anak lagi pada PUS saat menggunakan metode kontrasepsi jangka panjang dapat dilihat pada Tabel 1 .

Tabel 1 menunjukkan sebagian besar responden berkeinginan mempunyai anak lagi menggunakan Non-MKJP. Responden yang tidak berkeinginan mempunyai anak lagi menggunakan MKJP. Hubungan keinginan mempunyai anak lagi dengan penggunaan MKJP, menunjukkan nilai $\mathrm{p}=0,000(\mathrm{p}<\alpha, \alpha=0,05)$. Berarti bahwa terdapat hubungan bermakna antara keinginan mempunyai anak lagi dengan pengguna MKJP.

\section{Hubungan Dukungan Suami dan Keluarga dengan Keinginan PUS Menggunakan MKJP}

Dukungan suami dan keluarga pada responden saat menggunakan MKJP dapat dilihat pada Tabel 1 .

Tabel 1 menunjukkan mayoritas responden yang mendapat dukungan suami dan keluarga menggunakan Non-MKJP. Pada responden yang tidak mendapat dukungan suami dan keluarga menggunakan MKJP. Hubungan dukungan suami dan keluarga dengan keinginan PUS menggunakan MKJP, menunjukkan nilai $\mathrm{p}=0,000(\mathrm{p}<\alpha, \alpha=0,05)$. Berarti bahwa ada hubungan bermakna antara dukungan suami dan keluarga dengan pengguna MKJP.

\section{Pengaruh Keinginan PUS dalam Penggunaan MKJP}

Faktor yang memengaruhi keinginan PUS dalam penggunaan MKJP dilakukan uji regresi logistik ganda dapat dilihat pada Tabel 2.

Semua variabel yang memiliki hubungan dilakukan uji lebih jauh untuk mengetahui pengaruh dan peluang interaksi antar variabel dengan penggunaan MKJP. Uji yang digunakan adalah regresi logistik ganda. Hasil uji regresi logistik ganda diketahui ada empat variabel yang bermakna yaitu umur, efek samping, ingin punya anak lagi, dan dukungan suami dan keluarga. Variabel umur (1) dengan nilai $\mathrm{p}=0,002$ yang artinya bahwa antara umur $>30$ tahun dan $<20$ tahun tidak ada beda peluangnya untuk menjadi MKJP. Sedangkan umur (2) dengan nilai $p=0,002$ yang artinya responden umur $>30$ tahun mempunyai peluang 10,386 kali untuk menjadi MKJP dibandingkan responden umur 20 30 tahun.

Pada variabel efek samping dengan nilai $\mathrm{p}=0,005$ yang artinya responden yang merasakan efek samping tidak pernah berpeluang 8,726 kali untuk menjadi MKJP. Variabel keinginan mempunyai anak lagi dengan nilai $\mathrm{p}=0,028$ yang artinya responden yang tidak berkeinginan mempunyai anak lagi berpeluang 5,047 kali untuk menjadi MKJP. Variabel dukungan suami dan keluarga dengan nilai $p=0,008$ yang artinya responden dengan suami dan keluarga yang tidak mendukung berpeluang 7,579 kali untuk menjadi MKJP.

Tabel 2. Hasil Uji Regresi Logistik Ganda pada Variabel

\begin{tabular}{|c|c|c|c|}
\hline Variabel & B & $\mathbf{p}$ & OR \\
\hline Umur (1) & 21,208 & 0,002 & 0,00 \\
\hline $\begin{array}{l}\text { Umur }(2) \\
\operatorname{Ref}(>30 \text { tahun })\end{array}$ & 2,340 & 0,002 & 10,386 \\
\hline $\begin{array}{l}\text { Efek samping (1) } \\
\text { Ref (Tidak pernah) }\end{array}$ & 2,166 & 0,005 & 8,726 \\
\hline $\begin{array}{l}\text { Ingin punya anak lagi (1) } \\
\text { Ref (Tidak setuju) }\end{array}$ & 1,619 & 0,028 & 5,047 \\
\hline $\begin{array}{l}\text { Dukungan suami dan keluarga (1) } \\
\text { Ref (Tidak) }\end{array}$ & 2,025 & 0,008 & 7,579 \\
\hline
\end{tabular}




\section{PEMBAHASAN}

Hasil dari penelitian di atas, diketahui bahwa variabel umur responden yang menggunakan Non-MKJP sebagian besar berumur 20-30 tahun dan responden yang menggunakan MKJP sebagian besar berumur $>30$ tahun. Menurut Notoatmodjo (2003), umur adalah salah satu faktor yang bisa memengaruhi seseorang untuk berperilaku termasuk dalam pemilihan alat kontrasepsi yang dipakai. Seorang wanita yang masih berumur muda mempunyai lebih kecil peluang untuk menggunakan MKJP dibandingkan dengan yang sudah berumur tua. Umur wanita $>$ 30 tahun sebaiknya mengakhiri kehamilannya setelah melahirkan 2 atau lebih dari 2 orang anak. Penelitian ini sejalan dengan penelitian yang di lakukan oleh Kusmawati (2006), yang menyatakan bahwa terdapat hubungan antara umur dengan pemilihan alat kontrasepsi yang di gunakan responden. Data yang diperoleh menunjukkan persentase sebagian besar usia 2030 tahun tergolong kategori reproduksi aman.

Wanita saling berinteraksi satu sama lain dan saling memengaruhi. Responden dalam masa reproduksi ini masih memiliki peluang besar untuk memiliki anak. Usia wanita yang muda lebih besar keinginan untuk memiliki anak daripada usia wanita yang berumur tua. Sebagian besar responden lebih memilih menggunakan Non-MKJP dari pada MKJP karena lebih cepat untuk mengembalikan kesuburan. Apabila sewaktu-waktu ingin merencanakan menambah anak tidak perlu repot untuk pergi ke tempat pelayanan kesehatan untuk melepas alat kontrasepsi. Responden dengan persentase sebagian kecil mempunyai kategori usia berisiko yaitu terletak pada umur $<20$ tahun dan $>35$ tahun. Usia $<20$ tahun memiliki risiko besar untuk menggunakan alat kontrasepsi di mana organ reproduksi belum berfungsi sempurna. Sedangkan usia $>35$ tahun merupakan rawan untuk memiliki anak lagi, alat reproduksi sudah tidak sekuat usia 20-30 tahun, sehingga diwajibkan untuk mengakhiri kehamilan nya dengan menggunakan MKJP. Penelitian ini tidak sejalan dengan penelitian yang dilakukan oleh Ariana (2012) yang menyatakan bahwa masih rendahnya jumlah akseptor MKJP dibandingkan dengan Non-MKJP yang terjadi pada pasangan usia subur tidak berpengaruh dengan usia akseptor KB. Usia hanya sebagai faktor intrinsik saat pemakaian alat kontrasepsi KB. Usia memiliki hubungan dengan struktur organ, fungsi fisiologi, penyusun komposisi biokimiawi, dan hormonal dalam sistem tubuh. Pada saat periode tertentu usia menyebabkan adanya perbedaan kebutuhan akan kontrasepsi.

Penggunaan alat kontrasepsi KB memiliki keunggulan dan kelemahan. Adapun kelemahan yang terjadi dari penggunaan alat kontrasepsi KB yaitu efek samping yang sering di alami responden. Efek samping tersebut meliputi keluar bercak-bercak darah di antara siklus menstruasi dan adanya keputihan yang berlebihan. Masih banyak wanita yang kesulitan saat menentukan metode kontrasepsi yang tepat untuk digunakan. Hal ini menunjukkan masih terbatasnya metode yang tersedia, serta ketidaktahuan masyarakat tentang persyaratan yang harus dipenuhi dan keamanan metode kontrasepsi. Ada beberapa faktor yang perlu dipertimbangkan, salah satunya adalah status kesehatan wanita, adanya efek samping yang potensial terjadi, angka kegagalan yang tinggi atau kehamilan yang tidak direncanakan. Penelitian ini sesuai dengan BKKBN (2011) yang menyatakan bahwa angka drop out dari pemakaian KB bisa disebabkan dari efek samping yang ditimbulkan dari penggunaan kontrasepsi. Efek samping yang sering terjadi yaitu haid tidak teratur, berat badan yang sering naik, nyeri perut atau dismenorrhoe. Wanita PUS pada masa posisi menunda kehamilan diarahkan menggunakan metode sederhana. Metode ini bisa mengembalikan kesuburan dengan mudah, namun masih tingginya tingkat kegagalan pada penggunaan metode ini. Sedangkan pada masa usia menjarangkan kehamilan dianjurkan menggunakan metode kontrasepsi yang efektif yaitu hormonal, namun memiliki efek samping yang lebih banyak daripada metode sederhana. Efek samping yang ditimbulkan yaitu kegemukan, jantung, dan varices. Jika ingin mengganti metode kontrasepsi lain yang sesuai dengan kebutuhan kondisi fisiknya, disarankan untuk konsultasi ke petugas kesehatan. PUS yang berkeinginan untuk mengakhiri kehamilan atau kesuburannya telah memiliki anak 2 atau lebih dari 3 orang dan berusia lebih dari 35 tahun metode kontrasepsi yang tepat yaitu MOP dan 
MOW. Metode kontrasepsi mantap ini cukup sekali untuk mengurangi efek samping. Penelitian ini tidak sesuai dengan penelitian yang dilakukan oleh Nawirah (2013), yang menyatakan bahwa akseptor yang mengalami efek samping setelah pemakaian alat kontrasepsi KB lebih sedikit, sedangkan yang tidak mengalami efek samping lebih banyak. Kondisi tubuh seorang wanita berbeda-beda ada yang tidak mengalami efek samping, namun ada juga banyak yang mengeluh mengalami efek samping dari pemakaian alat kontrasepsi. Hal ini perlu dikonselingkan ke petugas kesehatan terutama dokter dan bidan yang lebih mengerti tentang program KB. Pemberian informasi dan konseling yang lengkap dan jelas akan memudahkan akseptor untuk memantapkan pemakaian alat kontrasepsi, untuk pengambilan tindakan yang cepat dan tepat apabila sedang mengalami efek samping dan mengurangi terjadinya efek samping dari pemakaian alat kontrasepsi yang sudah dipilih dan digunakan akseptor. Penyedia pelayanan KB menggali lebih dalam lagi permasalahan yang sering dialami oleh akseptor saat konseling berlangsung. Penyedia pelayanan KB memberikan kualitas pelayanan KB dengan cara membantu akseptor untuk memilih dan memastikan bahwa pilihan baik dan aman. Sampai saat ini masih belum ada metode kontrasepsi yang sempurna tanpa ada risiko dari efek samping. Semua metode kontrasepsi mempunyai keunggulan dan kelemahan masing-masing. Pada umumnya alat kontrasepsi $\mathrm{KB}$ masih terjual bebas dan akseptor bisa leluasa memilih metode kontrasepsi apa yang akan digunakan tanpa memikirkan akibat dari kontraindikasi yang ditimbulkan.

Keluarga yang memiliki anak satu masih memungkinkan pasangan tersebut untuk menambah anggota keluarga baru. Keinginan mempunyai anak lagi memengaruhi penggunaan metode KB yang dipakai. Anak adalah harapan dari sebuah cinta tali perkawinan. Berapa jumlah anak yang diinginkan tergantung dari keputusan keluarga itu sendiri. Ada keluarga yang menginginkan jumlah anak satu, dua, tiga dan seterusnya sesuai dengan kemampuannya. Keputusan untuk memiliki anak lagi adalah pilihan. Pilihan yang dipengaruhi oleh nilai yang dianggap sangat penting sebagai salah satu harapan atas keinginan yang sudah dipilih orang tua. Sesuai dengan penelitian Novitalia (2009), keinginan suami untuk mempunyai anak lagi sangat berperan saat istri memilih menggunakan alat kontrasepsi KB. Suami tidak akan memberi batasan kepada istri untuk mengakses pelayanan $\mathrm{KB}$ yang diinginkan. Jika sudah melahirkan istri bisa memilih metode kontrasepsi yang akan digunakan sesuai dengan pilihannya. Penelitian ini didukung oleh penelitian Maryatun (2007), yang menyatakan bahwa keinginan memiliki anak disesuaikan dengan jumlah anak yang ideal yang sebelumnya sudah diputuskan pasangan suami istri untuk dimilikinya. Hal ini sangat berkaitan dengan masalah ekonomi keluarga, biaya membesarkan anak, dan tingkat pendidikan. Keinginan memiliki anak sangat dipengaruhi adanya ketersediaan program KB. Penelitian ini tidak sesuai dengan penelitian yang dilakukan oleh Yanuar (2010), yang menyatakan bahwa pemilihan metode kontrasepsi sangat dipengaruhi oleh jumlah anak yang dimilikinya. Jika PUS memiliki banyak anak maka semakin besar untuk memilih alat kontrasepsi mantap sebagai pilihan untuk menghentikan kesuburan atau tidak hamil lagi. Metode mantap ini yaitu MOW yaitu bagian dari saluran telur di potong atau diberi cincin sehingga tidak bertemu antara sel telur dengan sperma. Metode mantap yang lain adalah MOP yaitu bagian dari saluran sperma di potong atau diberi cincin untuk menghentikan produksi sperma.

Dukungan dari suami dan keluarga sangat penting saat pemilihan alat kontrasepsi. Suami dan keluarga merupakan orang terdekat yang bisa diajak diskusi dan orang yang dipercaya. Dukungan suami merupakan faktor yang sangat penting jika dibandingkan dengan faktor lainnya yang bisa saja diabaikan. Seorang wanita yang sudah menikah sangat membutuhkan dukungan suami dan keluarga. Suami dan keluarga memiliki pengaruh sangat besar terhadap pilihan alat kontrasepsi KB yang akan dipakai. Penggunaan alat kontrasepsi KB akan dilakukan jika seorang wanita lebih percaya dengan suaminya untuk mendukung menggunakan alat kontrasepsi. Berkebalikannya dengan penggunaan alat kontrasepsi, akan berkurang jika suami tidak mendukung istrinya untuk menggunakan alat kontrasepsi. Suami lebih mendominasi untuk mengarahkan, memilih 
dan mengakhiri alat kontrasepsi yang akan digunakan. Keputusan suami harus dipatuhi oleh istri. Penelitian yang dilakukan oleh Widiyawati (2012), yang menyatakan bahwa dukungan dari suami berhubungan dengan penggunaan alat kontrasepsi KB. Dukungan dari suami dan keluarga berpengaruh besar terhadap ibu untuk memantapkan pilihannya saat memilih alat kontrasepsi yang akan di gunakan. Pengambil keputusan tertinggi adalah suami yang dianggap sebagai pemimpin serta pencari nafkah di dalam keluarga. Pengambilan keputusan penggunaan alat kontrasepsi KB juga demikian. Dukungan suami saat mengikuti konseling KB sangat membantu pengambilan keputusan program $\mathrm{KB}$ apa yang akan digunakan oleh istrinya. Peran suami saat ikut konseling memiliki dampak positif seperti mengingatkan istri untuk minum pil sesuai anjuran, jadwal kontrol ke petugas kesehatan. Begitu besar peran suami sangat membantu dan menyadarkan bahwa masalah kesehatan reproduksi tidak hanya untuk istri saja tetapi juga suami ikut terlibat didalamnya. Selain itu suami memberikan biaya khusus untuk memasang alat kontrasepsi, memilih tempat pelayanan kesehatan dan tenaga kesehatan yang layak untuk istrinya.

Selain dukungan dari suami, istri juga membutuhkan dukungan keluarga sebagai orang terdekat yang dapat dipercaya untuk membantu, mendorong serta memberikan saran atau pendapat yang telah diberikan. Telah dijelaskan dalam teori perilaku bahwa dukungan suami adalah faktor pendorong yang bisa memengaruhi perilaku seorang istri berhubungan dengan perilaku kesehatan, oleh sebab itu perlu perhatian besar dalam pelaksanaan kegiatan program keluarga berencana. Jika ingin program KB berjalan sukses semua harus dilibatkan termasuk dukungan suami dan keluarga.

\section{SIMPULAN DAN SARAN}

\section{Simpulan}

Umur, efek samping, keinginan mempunyai anak lagi, dukungan suami dan keluarga memengaruhi keinginan PUS menggunakan MKJP di wilayah kerja Puskesmas Pacar Keling Surabaya. Hasil penelitian menunjukkan peluang lebih besar menggunakan MKJP adalah responden pada kategori umur $>30$ tahun. Pada masa umur ini ketika ingin mengakhiri kehamilan dan tidak berkeinginan untuk menambah jumlah anak dalam anggota keluarga. Responden yang tidak mengalami efek samping dari penggunaan alat kontrasepsi KB yang menggunakan MKJP memiliki efek samping lebih sedikit dari pada Non-MKJP. Banyak wanita usia subur yang takut menggunakan MKJP karena pemasangan alat kontrasepsi ini di masukkan ke dalam lapisan kulit dan organ tubuh wanita. Responden yang sudah tidak berkeinginan mempunyai anak lagi. Penggunaan MKJP lebih mengarah untuk mengakhiri kehamilan. Banyak yang memilih kontrasepsi mantap untuk menghindari kehamilan yang tidak direncanakan oleh PUS. Suami dan keluarga wanita PUS tidak mendukung untuk pemakaian alat kontrasepsi yang dipilih oleh istri. Semua keputusan ada di tangan suami, jika tidak mendapat dukungan dari suami maka istri patuh terhadap pilihan dari suami. Keluarga sebagai pihak terdekat untuk meminta saran.

\section{Saran}

Berdasarkan hasil analisis penelitian ini disarankan bagi petugas kesehatan KB untuk memberikan konseling dan informasi pada PUS yang berumur antara 20-30 tahun tentang penjelasan penggunaan MKJP yang aman. Konseling merupakan bagian terpenting untuk memberi penjelasan dan pendekatan kepada PUS. Pada saat memberikan konseling istri harus mengajak suami turut serta saat pemilihan alat kontrasepsi yang cocok dan sesuai dengan pilihannya. Suami mencarikan informasi tambahan untuk menambah sebagai wawasan tentang alat kontrasepsi jangka panjang yang digunakan oleh istrinya. Wanita PUS tidak perlu takut saat pemasangan IUD, Implant, MOW dan MOP, sudah ada petugas pelayanan KB yang ahli dalam memasang alat $\mathrm{KB}$.

\section{DAFTAR PUSTAKA}

Ariana, P. 2012.Determinan Akseptor Kontrasepsi Jangka Panjang dan Akseptor Jangka Pendek Pada Wanita PUS di Puskesmas Gading Surabaya. Skripsi. Surabaya: Universitas Airlangga 
BKKBN. 2011. Grand desain Bidan KB dan KR. Jakarta

BKKBN. 2011. Pelayanan Keluarga Berencana. Jakarta: BKKBN

BKKBN. 2014. Pemantauan Pasangan Usia Subur Melalui Mini Survei 2013. Jakarta: BKKBN

Kurnia. 2008. Pengetahuan Kontrasepsi Pada Suami Ditinjau Dari Umur, Pendidikan dan Pekerjaan. Jurnal. Surabaya: Universitas Airlangga

Kusmawati. 2006. Hubungan Antara Umur Ibu dengan Pemilihan Alat Kontrasepsi di Klinik dr. F Surabaya. Karya Tulis Ilmiah. Surabaya: Stikes Rumah Sakit Islam Surabaya

Manuaba, IBG., Chanranita, IA., Fajar, IBG. 2009. Memahami Kesehatan Reproduksi Wanita. Jakarta: Media Aesculapius

Maryatun. 2007. Analisa Faktor-Faktor Pada Ibu yang Berpengaruh Terhadap Pemakaian Metode Kontrasepsi IUD di Kabupaten Sukoharjo. Tesis. Semarang: UNDIP

Nawirah. 2013. Faktor yang Memengaruhi Pemilihan Kontrasepsi IUD di Wilayah Kerja Puskesmas Wonomulyo Kecamatan Wonomulyo Kabupaten Polman. Jurnal. Polman: Universitas Hasanudin

Notoatmodjo, S. 2003. Pendidikan dan Perilaku Kesehatan. Jakarta: Rineka Cipta
Novitalia, S. 2009. Analisis Faktor Perilaku Keluarga Berencana dan Relasi Gender Dalam Unmeet Need Kontrasepsi Pada Wanita di Kota Surabaya. Skripsi. Surabaya: Universitas Airlangga.

Sumartini. 2016. Faktor yang Berpengaruh Terhadap Keinginan PUS Dalam Penggunaan Metode Kontrasepsi Jangka Panjang Di Wilayah Kerja Puskesmas Pacar Keling Surabaya. Skripsi. Surabaya: Universitas Airlangga

Susenas. 2012. Survei Sosial Ekonomi Nasional tahun 2012

Widiyawati, S., Nyorong, M., Natsir, S. 2012. Faktor-faktor yang Berhubungan dengan Pemakaian AKDR di Wilayah Kerja Puskesmas Batuah Kutai Kartanegara. Tesis. Makasar: Universitas Hasanudin

Witjaksono, J. 2012. Rencana Aksi Keluarga Berencana dan Kesehatan Reproduksi Tahun 2012-2014. Jakarta: BKKBN

Yanuar. 2010. Pengaruh Pengetahuan dan Sikap Pasangan Usia Subur Tentang KB Terhadap Pemilihan Kontrasepsi di Lingkungan Kelurahan Joho Kecamatan Sukoharjo. Skripsi. Yogyakarta: UGM 